\title{
Conservation tillage and cover cropping influence soil properties in San Joaquin Valley cotton-tomato crop
}

by Jessica J. Veenstra, William R. Horwath, Jeffrey P. Mitchell and Daniel S. Munk

Following 4 years of a cotton-tomato rotation on the west side of the San Joaquin Valley, conservation tillage and cover crops altered physical and chemical properties of soil. In conservation tillage systems, bulk density decreased and available concentrations of nitrate and phosphorus increased. In contrast, the conservation tillage system redistributed potassium to the surface of the soil, lost organic matter and increased salt concentrations, all potentially detrimental to plant growth. Cover cropping, on the other hand, increased soil organic matter regardless of the tillage treatment, and increased potassium concentrations. By cover cropping, farmers in this region may improve their soil quality; however, the benefits of conservation tillage to soil quality are fewer and will require more research to determine longterm effects.

Tntensive tillage practices are contributing to declining air, water and soil quality in California's Central Valley. Reducing soil disturbance by implementing conservation tillage practices may improve this situation. Conservation tillage is defined as any tillage system that leaves $30 \%$ or more of the soil surface covered with crop residue after planting. Conservation tillage reduces dust emissions from agricultural fields by decreasing the frequency and intensity of tillage operations. Limiting soil disturbance has been shown to improve the soil's tilth and fertility, increase water infiltration, increase organic matter storage and reduce erosion (Holland 2004; Uri et al. 1998). However, these benefits may be dependent upon cropping system, climate and soil

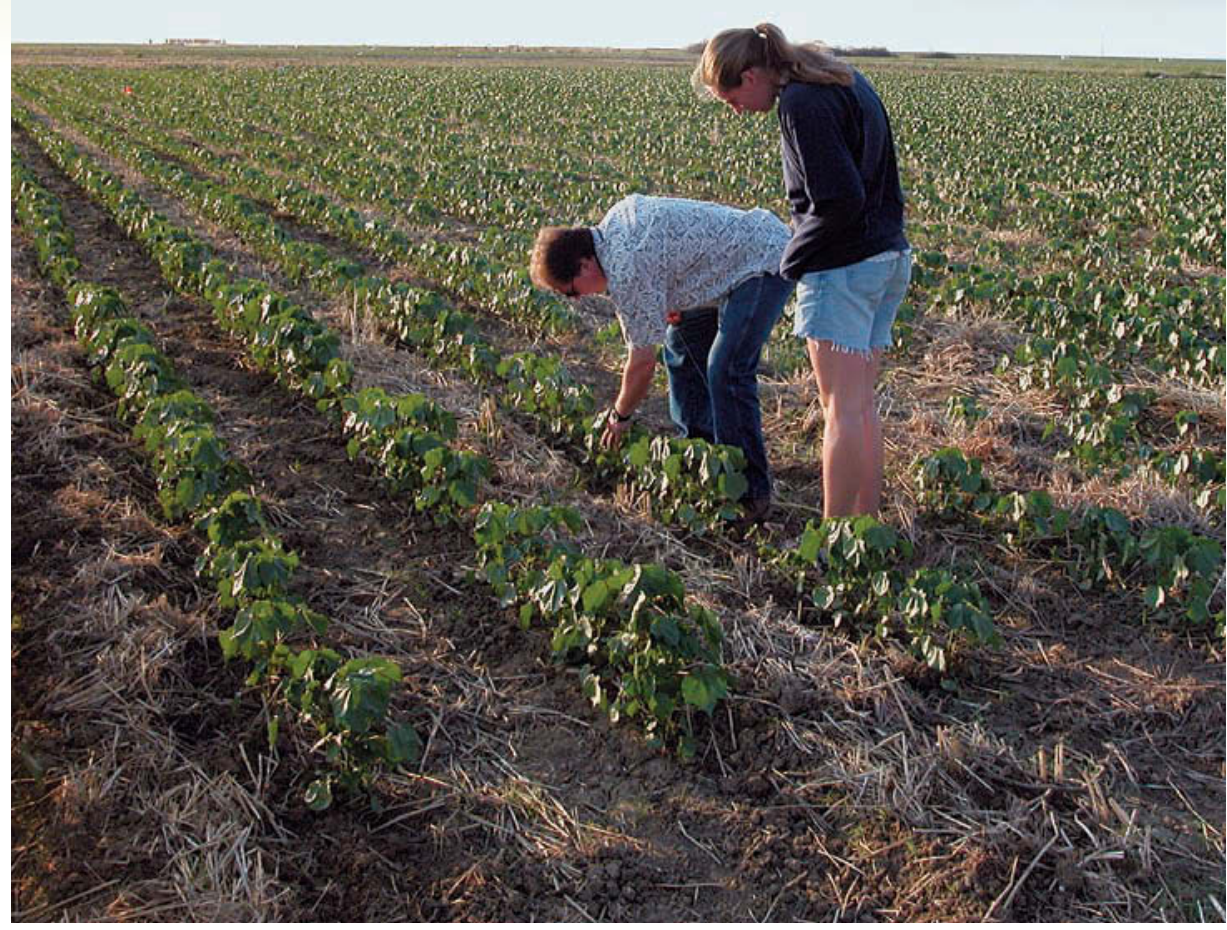

William Horwath, UC Davis professor of land, air and water resources, and Jessica Veenstra, graduate student at lowa State University, examine cotton plants for a 4-year study of the effects of conservation tillage - with and without cover crops - on soil quality.

type, so it is important to determine if conservation tillage will provide the same benefits to California agriculture, with its diversity of cropping systems, warm, semiarid climate and variety of soil types.

While reduced-tillage systems are common in the Midwest and South, conservation tillage is seldom practiced in California. Growers perceive its adoption to be difficult because tillage aids weed and disease management, loosens compacted soils and allows for the efficient distribution of irrigation water in furrows. California growers consider tillage necessary to maintain the high yields typical of the state's field and row-crop systems. On the other hand, conventional tillage operations consume considerable energy and increase equipment and labor needs, so there may be an economic benefit to converting to conservation tillage. Conservation tillage crop production practices may help reduce the environmental impacts and production costs of California agriculture.

\section{Role of soil organic matter}

Frequent tillage can reduce the amount of organic matter in soil, an important aspect of its quality. Soil organic matter refers to all of the organic material in soils, including decaying plant material, soil microbes and humified substances. Organic matter improves the biological, chemical and physical properties of soil and provides readily available nutrients for plant and microbial uptake. Properly managed soil organic matter can increase nutrient availability to plants, which may allow farmers to reduce fertilizer use (Reeves 1997).

Through interactions with minerals, organic matter can improve the physical properties of soil, including aggregate stability, aeration, waterholding capacity and water infiltration. By disrupting soil aggregates, intensive tillage exposes protected organic matter to increased microbial activity, which leads to its loss as carbon dioxide. In contrast, by decreasing soil disturbance, conservation tillage 


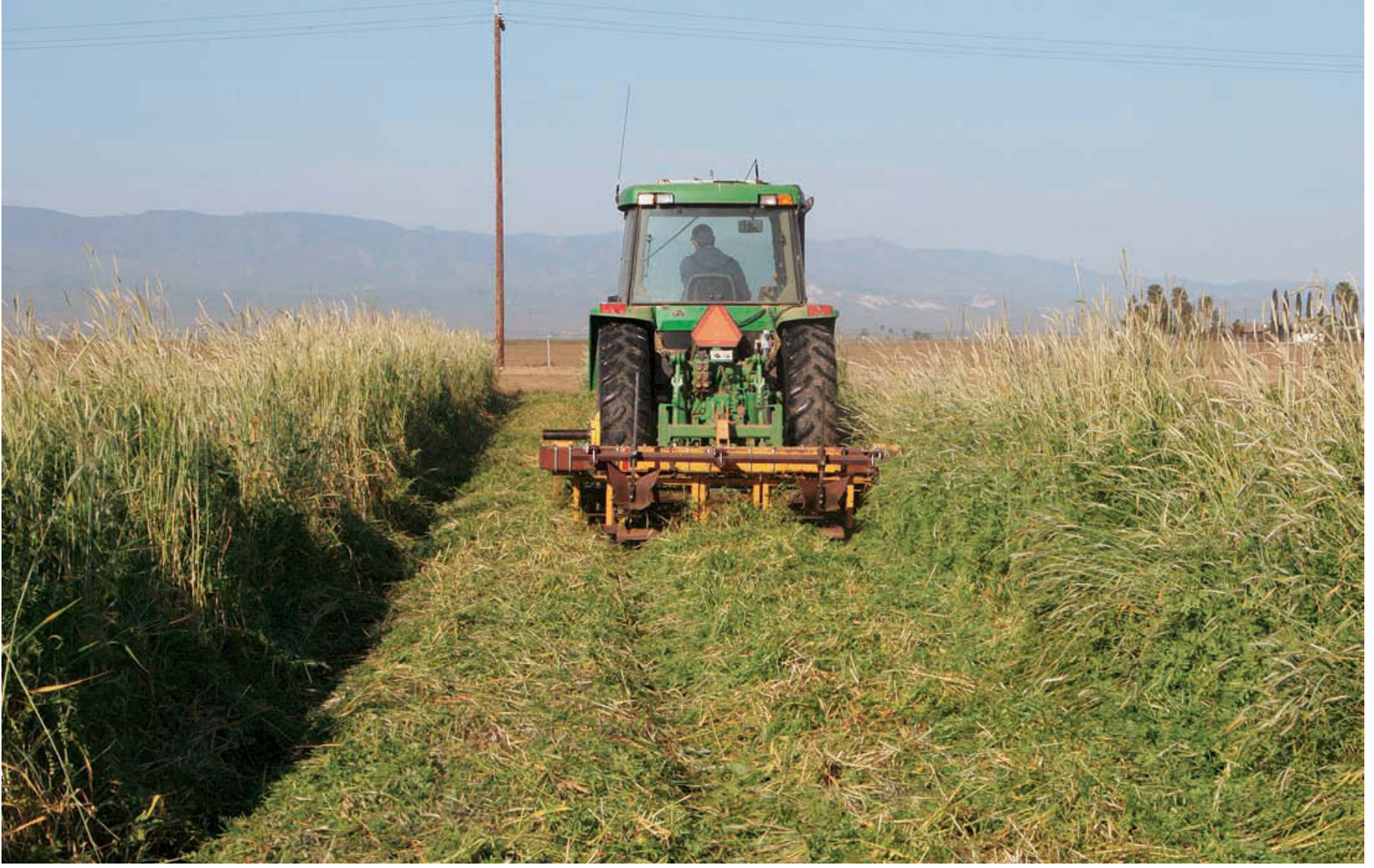

One challenge of growing cover crops with conservation tillage is managing the residue to avoid complications with furrow irrigation.

systems have the potential to accumulate organic matter in some geographic regions. In other regions, conservation tillage redistributes organic matter to the soil surface while decreasing organic matter in the subsurface, depending on soil type and climate.

Adding organic matter as a cover crop can also benefit crop growth and improve soil quality. Cover crops can be legumes such as vetches or clovers, which fix nitrogen, or nonlegumes such as ryegrass or sudangrass, which immobilize nitrogen prone to leaching. Legume cover crops can add up to 89 pounds nitrogen per acre (100 kilograms nitrogen per hectare) through biological nitrogen fixation (Poudel et al. 2001). Cereal and grass cover crops can act as a "catch crop" to tie up nitrates during winter rains, preventing them from leaching into ground or surface waters. Mixtures of legume and cereal cover crops can perform both functions.

Cover crops also increase organic matter by increasing the amount of biomass added to the soil. The additional biomass of cover crops can be incorporated into the soil as a green manure in standard tillage systems or left on the surface as mulch in conservation tillage systems. When left on the surface, cover crop residues have been shown to effectively control weeds, reduce soil erosion and conserve soil moisture by reducing evaporation (Hartwig and Ammon 2002; Lu et al. 2000). In
California, the use of conservation tillage and cover cropping together is especially uncommon in field and rowcrop systems.

\section{Evaluating tillage practices}

We evaluated the effects of conservation tillage and cover cropping on physical and chemical soil properties in a tomato-cotton rotation typical of

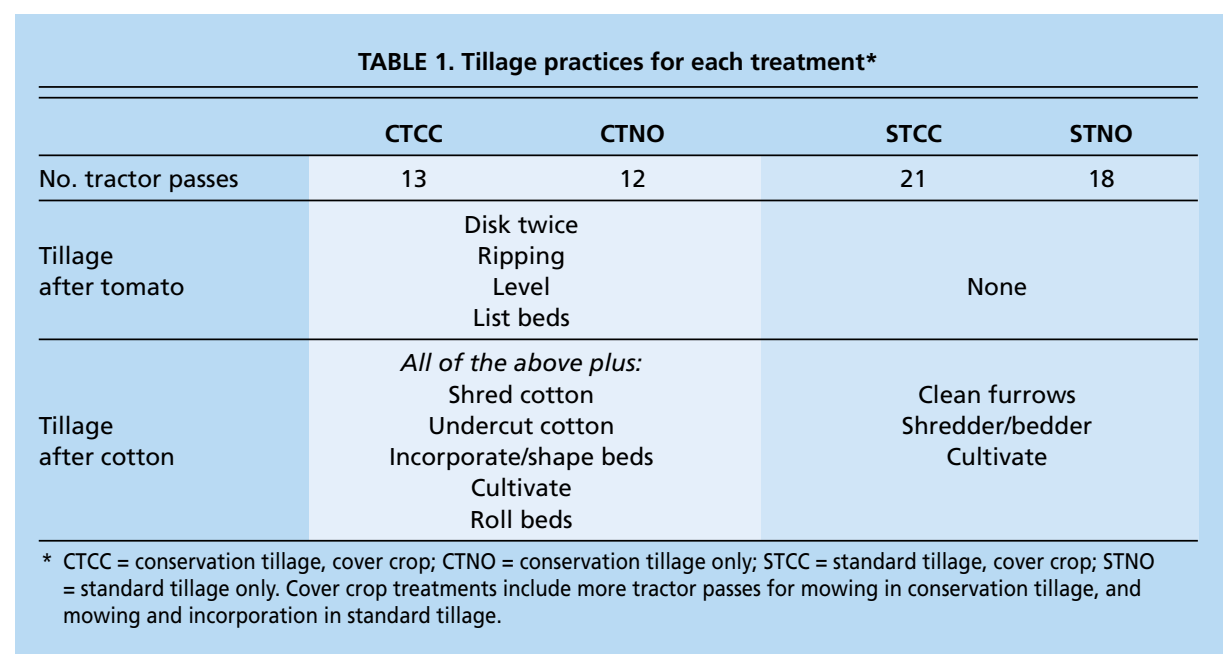




\section{TREATMENTS}

CTCC: conservation tillage, cover crop

CTNO: conservation tillage only

STCC: standard tillage, cover crop

STNO: standard tillage only

the San Joaquin Valley. In 1999, we established a field experiment comparing standard and conservation tillage systems at the UC West Side Research and Extension Center (WSREC) in Five Points. The area generally receives only 7 inches of precipitation per year and has an average annual temperature of $63^{\circ} \mathrm{F}$. These field plots are California's longest existing field research of conservation tillage systems.

Four treatments were applied: (1) conservation tillage with cover crop (CTCC); (2) conservation tillage, no cover crop (CTNO); (3) standard tillage with cover crop (STCC); and (4) standard tillage, no cover crop (STNO). Each treatment was replicated eight times and distributed randomly across the field. The treatments were split into four replicates each of tomato and cotton in alternating years. In this experiment, conservation tillage did not completely eliminate soil disturbance; rather, it reduced the number and intensity of tillage passes (table 1). The winter cover crop was a cereal-legume mix of Juan triticale $(30 \%)$, Merced ryegrain $(30 \%)$ and common vetch $(40 \%)$.

Soils were sampled to two depths ( 0 to 6 inches and 6 to 12 inches) in the spring before planting and after the fall harvest. Total carbon and nitrogen were measured using a Carlo Erba carbon and nitrogen analyzer. The DANR Analytical Laboratory analyzed soil samples for the following soil properties: $\mathrm{pH}$, electrical conductivity, nitratenitrogen, ammonium-nitrogen, and extractable potassium and phosphorus. The treatments and sampling protocols were repeated for four growing seasons. We applied a three-way ANOVA and Tukey's honestly significant difference (HSD) test to each dataset in order to determine significant differences between means (Tukey 1953).

TABLE 2. Soil bulk density in 2003, after 4 years of treatment*

\begin{tabular}{|c|c|c|c|c|}
\hline Treatment & СТСC & CTNO & STCC & STNO \\
\hline $0-6$ inches & \multicolumn{4}{|c|}{ 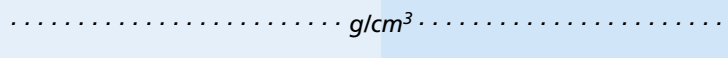 } \\
\hline Average & $1.20 \mathrm{bt}$ & $1.05 \mathrm{a}$ & $1.28 c$ & $1.24 b c$ \\
\hline Std. error & 0.036 & 0.015 & 0.034 & 0.021 \\
\hline \multicolumn{5}{|l|}{ 6-12 inches } \\
\hline Average & $1.42 \mathrm{e}$ & $1.36 \mathrm{e}$ & $1.37 \mathrm{e}$ & $1.35 d$ \\
\hline Std. error & 0.057 & 0.030 & 0.041 & 0.026 \\
\hline
\end{tabular}

\section{Physical properties of soil}

Texture. Soil texture was measured by the hydrometer method. In our study, soil texture varied across the field. The north half of the field was sandy clay loam with $51 \%$ sand, $24 \%$ silt and 25\% clay, whereas the south half had a finer texture of clay loam with $36 \%$ sand, $33 \%$ silt and $31 \%$ clay. The treatments were blocked and randomly distributed across the field to account for the variance in texture.

Bulk density. Bulk density is a measure of soil's weight or mass per unit volume; soil with lower bulk density has more pore space and allows for more water infiltration and space for roots to grow than soil with higher bulk density. After 4 years of conservation tillage and cover cropping, we found bulk density differences in the surface 6 inches of soil (table 2). Soil bulk density was lowest with conservation tillage and highest with standard tillage. Bulk density was higher in the 6- to 12-inch depth than in the surface 0 to 6 inches for all treatments.

Changes in bulk density can usually be correlated to changes in the soil's organic matter. Organic matter organizes soil mineral particles into structural units that improve porosity, thereby decreasing bulk density. In our study, organic matter (total soil carbon) and bulk density were not correlated. Instead, bulk density more closely corresponded to the number of tractor passes required to manage each system. Each time the tractor passes across the field it compresses the soil and increases the bulk density. Generally, standard tillage and cover cropping treatments require more tractor passes; as expected, these treatments had higher bulk densities.
However, in our study CTCC required only one more tractor pass than CTNO, but its bulk density was 1.20 grams per square centimeter $\left(\mathrm{g} / \mathrm{cm}^{3}\right)$ as compared to $1.05 \mathrm{~g} / \mathrm{cm}^{3}$, respectively. This significant difference is difficult to explain by the loss of one tractor pass. Unfortunately, bulk density was not measured when the study began, so we cannot make a timezero comparison. Nonetheless, the treatments were randomly distributed across the field, and the differences between treatment means after 4 years of conservation tillage seem larger than would be found initially across a uniformly treated field. In this study, soil bulk density generally increased with increased compaction from tractor use, but we would expect these short-term observations to change as organic matter increases in the cover crop treatments.

Penetration resistance. Penetrometer resistance measurements of soil can be used to assess the need for tillage operations, which help maintain effective plant rooting and facilitate good water and nutrient uptake. Because deep tillage was eliminated in the conservation tillage plots, there was some concern that root penetration in the deep soil zones of those plots would be limited as a result of compaction caused by the equipment used for harvest, tillage and other cultural practices.

Our resistance measurements found little difference in soil compaction in the 0 - to 9-inch depth, and the standard tillage plots had higher soil resistances at the 9- to 18-inch depth compared to the conservation tillage plots (fig. 1). These differences provided evidence that a compacted layer or plow pan was developing. This is caused by additional tillage activities during the spring, at a time when the moisture content in the subsoil is high and soils are more vulnerable to compaction. 
yields can drop by 10\% (Maas 1986). Measured salt concentrations were within this boundary during our 4year study. (Cotton is more salt-tolerant than tomato.) If salts continue to concentrate at the surface in the CTNO treatment, the production of tomato and other salt-sensitive crops would be limited under conservation tillage, especially in parts of California where salt accumulation is a problem, such as the west side of the San Joaquin Valley. However, cover cropping may mitigate this potential salt accumulation.
Carbon. Total soil carbon is used to estimate soil organic matter, which is made up primarily of carbon. Soil organic matter is a reservoir of nutrients for plants and microorganisms; it helps to create soil structure, which gives the soil its porosity and allows more space for water and air, benefiting plant growth. Although we expected to see increases in total soil carbon with decreasing tillage, we actually found the largest loss in total carbon in the top 12 inches of soil in the CTNO treatment (table 3). This overall decrease may have been caused by the initial change in land use from barley to a cotton-tomato rotation; the cotton and tomato crops may have provided less carbon input than the previous barley crop. The STNO system lost only half as much carbon as CTNO.

The standard tillage system incorporates crop residue into the soil, where it is transformed into organic matter by microbial action. In conservation tillage, crop residue is not mixed into the soil mechanically. Instead, the system is dependent upon soil fauna such as beetles and worms to mix plant residue into the

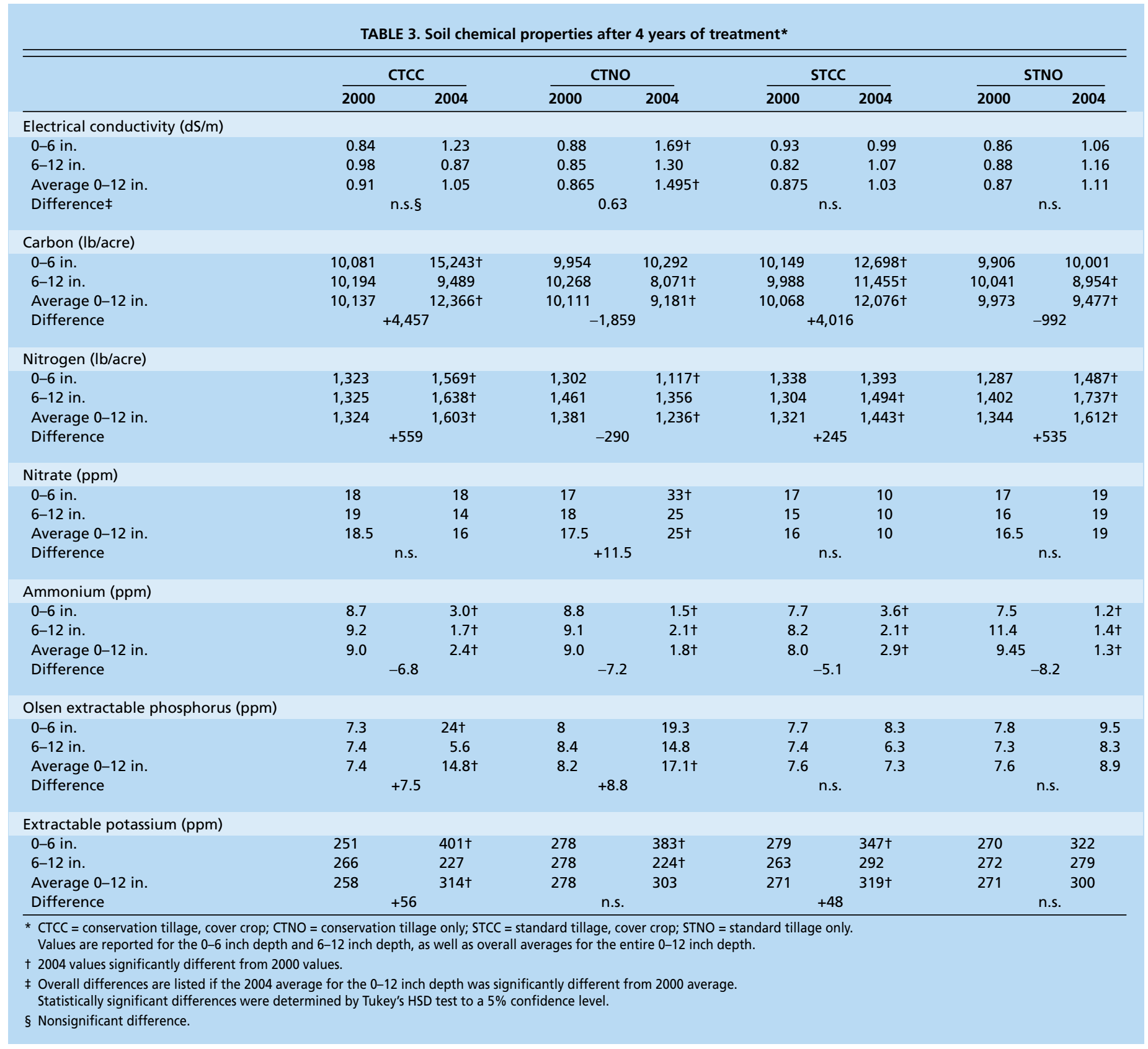


soil. Soil fauna populations may take more than 4 years to regenerate after decades of intensive tillage. In the conservation tillage systems, crop residue may be accumulating and mineralizing on the soil surface and not incorporating into soil to produce organic matter.

Researchers have found increases in total carbon with decreasing tillage, but most of this research was conducted in the temperate, humid, eastern half of the United States. Researchers in Texas found that soil carbon accumulation is inversely related to mean annual temperature, and that hot, dry conditions create a challenging environment for increasing soil carbon (Potter et al. 1998). The hot, dry conditions of the San Joaquin Valley's west side may limit the ability of conservation tillage to accumulate soil carbon in this region.

In our study, the addition of covercrop residues increased soil carbon regardless of tillage practice. CTCC and STCC increased total carbon by an average of 4,200 pounds per acre after 4 years. Cover crops, by adding more biomass to the system, increase carbon inputs to the soil. In CTCC, more carbon was found in the upper 6 inches, and

\section{After 4 years of conservation tillage, the soil's physical properties improved but its fertility degraded somewhat.}

there was no change in total carbon in the 6- to 12-inch depth. Carbon accumulates in the upper 6 inches in conservation tillage because the crop residues are left on the surface and not tilled into the soil. Conversely, with STCC total carbon increased in both depths because the residues were incorporated and mixed into the soil. After 4 years, changes in total carbon were influenced more by cover-crop additions than tillage.

Other studies have shown that carbon increases in no-till systems in similar hot, semiarid climates after 10 years (Zibilske et al. 2002; Mrabet et al. 2001). Others found increases in total carbon at the surface after 10 years, but no overall carbon accumulation because of losses from lower depths (Hernanz et al. 2002). Also, conservation tillage in our study did not mean the complete elimination of soil disturbance; rather, the system included some cultivation in tomato and postharvest tillage in cotton. Even this reduced soil disturbance may have limited carbon accumulation in the conservation tillage systems.
TABLE 4. Total nitrogen (N) and carbon (C) budget after 4 years of treatment*

\begin{tabular}{|c|c|c|c|c|c|c|}
\hline \multicolumn{7}{|c|}{ Nitrogen } \\
\hline Crop & Treatmentt & Fertilizer & Cover crop & Total & Harvest & Balance \\
\hline \multicolumn{7}{|c|}{$\ldots \ldots \ldots \ldots \ldots \ldots \ldots+l b$ N/acre/yr } \\
\hline Cotton & CTCC & 45 & \multirow[t]{2}{*}{149} & 194 & 20 & 174 \\
\hline Cotton & CTNO & 45 & & 45 & 23 & 22 \\
\hline Cotton & STCC & 45 & \multirow[t]{2}{*}{118} & 163 & 24 & 139 \\
\hline Cotton & STNO & 45 & & 45 & 27 & 18 \\
\hline Tomato & CTCC & 69 & \multirow[t]{2}{*}{133} & 202 & 146 & 55 \\
\hline Tomato & CTNO & 69 & & 69 & 161 & -93 \\
\hline Tomato & STCC & 69 & \multirow[t]{2}{*}{103} & 171 & 146 & 26 \\
\hline Tomato & STNO & 69 & & 69 & 144 & -76 \\
\hline \multicolumn{7}{|l|}{ Carbon } \\
\hline \multirow[t]{2}{*}{ Crop } & Treatmentt & Crop carbon & Cover crop & Total & Harvest & Balance \\
\hline & \multicolumn{6}{|c|}{$\ldots \ldots \ldots \ldots \ldots \ldots \ldots+b$ lb Clacre/yr } \\
\hline Cotton & CTCC & 1,580 & \multirow{2}{*}{3,315} & 4,895 & 328 & 4,567 \\
\hline Cotton & CTNO & 1,779 & & 1,779 & 369 & 1,410 \\
\hline Cotton & STCC & 1,899 & \multirow[t]{2}{*}{2,618} & 4,516 & 394 & 4,122 \\
\hline Cotton & STNO & 2,088 & & 2,088 & 433 & 1,655 \\
\hline Tomato & СТСС & 1,169 & \multirow[t]{2}{*}{2,955} & 4,124 & 2,484 & 1,640 \\
\hline Tomato & CTNO & 1,288 & & 1,288 & 2,736 & $-1,448$ \\
\hline Tomato & STCC & 1,163 & \multirow[t]{2}{*}{2,288} & 3,451 & 2,472 & 979 \\
\hline Tomato & STNO & 1,152 & & 1,152 & 2,448 & $-1,296$ \\
\hline \multicolumn{7}{|c|}{$\begin{array}{l}\text { * For nitrogen, fertilizer nitrogen and cover-crop nitrogen are considered inputs, while harvested nitrogen is } \\
\text { considered an output. For carbon, crop carbon and cover-crop carbon are considered inputs, while harvested carbon } \\
\text { is considered an output. The balance is the nitrogen or carbon that should be remaining in the soil. }\end{array}$} \\
\hline \multicolumn{7}{|c|}{$\begin{array}{l}\text { + CTCC = conservation tillage, cover crop; CTNO = conservation tillage only; STCC = standard tillage, cover crop; STNO } \\
=\text { standard tillage only. }\end{array}$} \\
\hline
\end{tabular}

Nitrogen. Soil nitrogen is an important nutrient for plants and microbes; large amounts of nitrogen are needed to form amino acids, proteins and enzymes. In our study, CTNO lost 290 pounds nitrogen per acre after 4 years, while the rest of the treatments showed an overall accumulation of total nitrogen in the upper 12 inches of soil (table 3). CTCC increased by 559 pounds nitrogen per acre, and in STCC, total nitrogen increased by 245 pounds per acre. The increases in total nitrogen in these two systems are linked to the increased input of organic matter associated with the cover crop. However, the increase in total nitrogen in the STNO treatment was unexpected.

\section{Carbon and nitrogen dynamics}

In order to help us understand the carbon and nitrogen dynamics of this system, we calculated a carbon and nitrogen budget, in which we looked at all of the carbon and nitrogen inputs and removals from each system (table 4). For carbon, the remaining crop-residue carbon and cover-crop carbon were the inputs to the system, and the carbon removed with the harvested crop was the output. For nitrogen, fertilizer nitrogen and nitrogen fixed by cover crops were the inputs, and nitrogen removed by the harvested crop was the output. The balances of these inputs and outputs should predict the amount of carbon and nitrogen stored or lost by each of the treatments.

We compared the resulting balances to the overall increases and decreases in total soil carbon and nitrogen (table 5). Although the actual values were different, by and large the changes in total soil carbon corresponded to what was estimated by the budget. All of the actual total soil carbon values were about 1,100 to 1,800 pounds less than the expected values. This difference may be attributed to the fact that we only measured carbon in the surface 0 to 12 inches of soil. More soil carbon may be accumulating below 12 inches, especially from plant root inputs.

The differences between the budgeted and actual values of total soil 

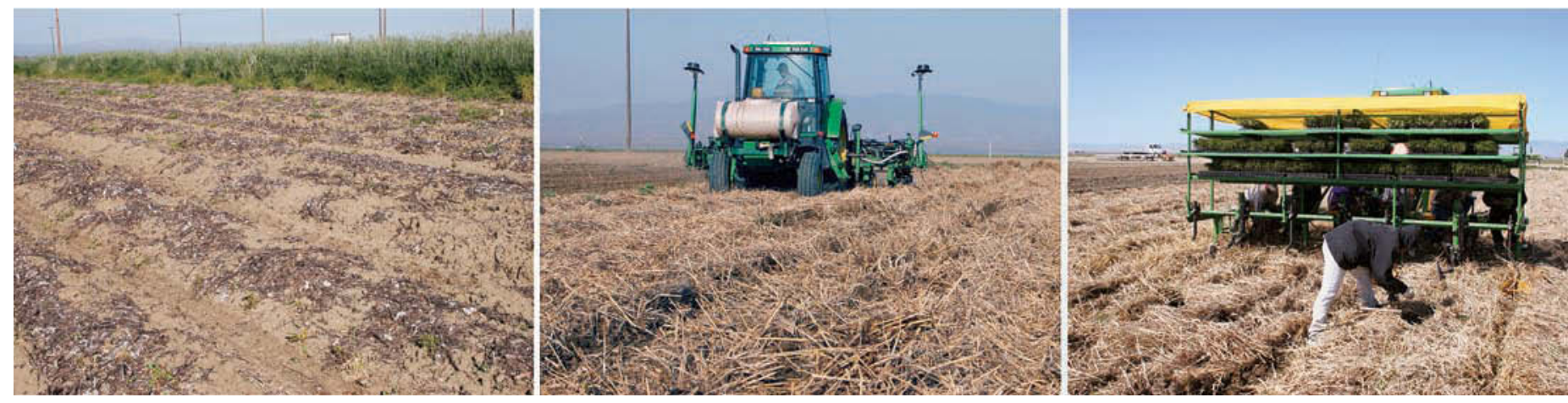

Cover crops in conjunction with conservation tillage helped to maintain soil fertility. Left, cotton and tomato crop residues prior to no-till transplanting; center and right, no-till cotton planting with a John Deere 1730 no-till transplanter directly into a cover crop of triticale-winter rye-vetch.

nitrogen were more variable. The CTCC and STNO treatments had much higher total soil nitrogen values than expected; STCC had a slightly larger value, while CTNO had a much larger loss than expected. Nitrogen is generally much harder to budget than carbon. The differences between the budgeted and actual values for the two cover-crop treatments suggest that the actual nitrogen fixation rate of the cover crop was larger than we estimated. The largest difference between expected and actual total soil nitrogen was in the STNO treatment, where we expected a total nitrogen loss and instead we saw an increase of 535 pounds nitrogen per acre. This difference is difficult to explain. The nitrogen budget does not account for nitrogen losses due to leaching or denitrification; these two processes may account

TABLE 5. Total nitrogen (N) and carbon (C) balance from the $\mathrm{N}$ and $\mathrm{C}$ budget (table 4) compared to total change in soil $\mathrm{N}$ and $\mathrm{C}$

\begin{tabular}{|c|c|c|}
\hline \multicolumn{3}{|l|}{ Nitrogen } \\
\hline Treatment* & Total balance & $\begin{array}{c}\text { Total } \\
\text { change in soil }\end{array}$ \\
\hline & \multicolumn{2}{|c|}{$\ldots \ldots \ldots$ lb N/acre/yr....} \\
\hline CTCC & 229 & 559 \\
\hline CTNO & -71 & -290 \\
\hline STCC & 165 & 245 \\
\hline STNO & -58 & 535 \\
\hline \multicolumn{3}{|l|}{ Carbon } \\
\hline \multirow[t]{2}{*}{ Treatment } & Total balance & $\begin{array}{c}\text { Total } \\
\text { change in soil }\end{array}$ \\
\hline & \multicolumn{2}{|c|}{$\ldots \ldots \cdot$ lb Clacre/yr.....} \\
\hline СТCC & 6,207 & 4,457 \\
\hline CTNO & -38 & $-1,859$ \\
\hline STCC & 5,101 & 4,016 \\
\hline STNO & 359 & -992 \\
\hline
\end{tabular}

for the higher than expected loss of total soil nitrogen in the CTNO treatment.

If total carbon and nitrogen values were used as an estimate for organic matter, we saw higher organic-matter mineralization potential in conservation tillage. This may be because the surface mulch allowed the soil to stay moist longer. In addition, as temperatures rose in the spring, more decomposition and mineralization occurred in the conservation tillage systems, so we saw overall losses of total carbon and nitrogen. But in the conservation tillage systems with cover crops, the extra biomass offset losses associated with the higher mineralization rate.

\section{Other minerals}

Nitrate. The nitrification of ammonia-based fertilizer results in nitrate, the form of nitrogen that is most easily taken up by plants. Although we expected to see improved nitrate conservation with cover cropping, in all treatments except CTNO, nitrate concentrations remained the same in both depths after 4 years of treatment. In CTNO nitrate concentrations increased in the surface 6 inches from 17 parts per million (ppm) to $33 \mathrm{ppm}$ (table 3).

Nitrate is a mobile ion that moves easily up and down the soil profile. With evaporation and upward water flow, nitrates can move to the surface, and without the physical mixing of tillage, the nitrate can stay in place and may contribute to salinity. In standard tillage systems where the profile is mixed regularly, nitrate is more evenly distributed throughout the profile. In the systems with cover crops, they take up nitrate, converting it to organic forms of nitrogen and preventing nitrate accumulation at the surface. In our study, conservation tillage systems accumulated nitrate in the surface (0 to 6 inches), while in standard tillage systems nitrate was evenly distributed throughout the upper 12 inches of soil.

Ammonium. Nitrogen fertilizer is often added to crops in the form of ammonia. All treatments and depths showed a decrease in ammonium concentrations after 4 years (table 3 ). These differences may be due to differences in the nitrification rate between the years, which could be affected by variations in winter temperatures and rainfall.

Phosphorus. Phosphorus is an essential component of DNA and RNA, making it another important plant nutrient. We found an overall increase in extractable phosphorus in both conservation tillage treatments, and phosphorus concentrations remained the same in both standard tillage treatments (table 3). In CTNO we saw an increase in each depth, but neither depth was considered significantly different than the 2000 value. With CTCC, the increase was in the 0 - to 6-inch depth.

Conservation tillage usually improves the availability of surface phosphorus by converting it into organic phosphorus. Crops take up phosphorus from below, "mining" and depositing it on the surface. In standard tillage systems this phosphorus would be remixed into the soil profile, whereas in conservation tillage it accumulates at the surface (Robbins and Voss 1991; Zibilske 2002). The CTNO treatment appeared to behave this way, but in CTCC we saw phosphorus increase in both depths. However, despite an overall increase in organic matter, the STCC treatment did not show phosphorus accumulation. 
Conservation of phosphorus may be a potential benefit of conservation tillage, improving phosphorus availability.

Potassium. After nitrogen and phosphorus, potassium is the nutrient most likely to limit plant production. In all treatments except STNO, potassium accumulated at the surface. Also, at the 6- to 12-inch depth, the potassium concentration remained the same, except in CTNO it decreased (table 3). In CTNO, crops took up potassium from the subsurface and deposited it as crop residue on the surface as organic matter. In the conservation tillage system the potassium stayed at the surface because it was not remixed by tillage. After 10 years of conservation tillage, Robbins and Voss (1991) found a similar redistribution of potassium to the soil surface. If this redistribution continues in our fields, it may eventually limit potassium availability to deeper-rooting crops or contribute to salinity problems. In the two cover-crop treatments, there was an overall potassium accumulation of about $100 \mathrm{ppm}$. By taking up and redistributing potassium to the soil surface, cover cropping and conservation tillage may be beneficial methods for conserving this important nutrient.

\section{Overall effects on soil quality}

In other parts of the United States, conservation tillage and cover cropping have been shown to improve soil quality. In our study, after 4 years of conservation tillage the soil's physical properties improved, but its fertility degraded somewhat. Bulk density and penetration resistance were lower in the conservation tillage systems; these soil properties improve water infiltration and conservation, and improve rooting depth. Conservation tillage increased available phosphorus but redistributed potassium from the subsurface to the surface by accumulating organic matter at the soil surface and not remixing it with tillage. Nitrate accumulated at the surface as well. By concentrating these

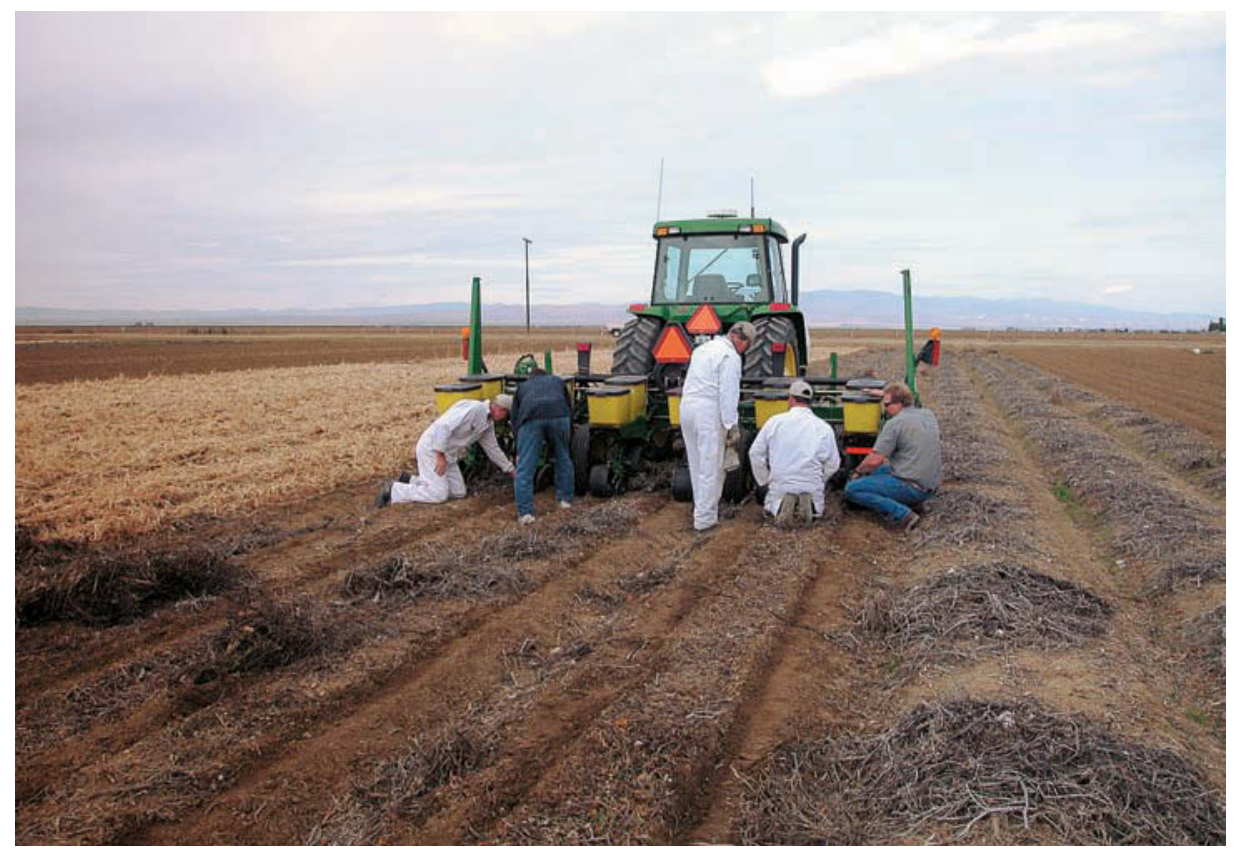

In this study, some soil parameters improved with conservation tillage, while others declined. For example, after 4 years of conservation tillage without a cover crop, soil salinity increased significantly. Above, researchers evaluate no-till planting into tomato residues.

nutrients at the surface, conservation tillage could limit crop growth and contribute to potential salinity problems.

This was seen in conservation tillage's affect on salt accumulation in the soil surface, which could create salt toxicity problems for crops with low salttolerance over the long term. With regard to organic matter or soil carbon - an important and beneficial property for long-term soil fertility and quality — we did not see any increases in the conservation tillage systems, but cover crops increased soil carbon significantly regardless of the tillage treatment. Cover cropping also increased total soil nitrogen, phosphorus and potassium, and in the conservation tillage treatments mitigated the increases in salt concentration. In the low-rainfall regime of the San Joaquin Valley, farmers may benefit more from cover cropping in combination with conservation or standard tillage to maintain soil fertility, as opposed to conservation tillage alone.

J.J. Veenstra is Graduate Student, Department of Agronomy, lowa State University, and formerly Graduate Student, Department of Land, Air and Water Resources, UC Davis, and W.R. Horwath is Professor, Department of Land, Air and Water Resources, UC Davis; J.P. Mitchell is Cooperative Extension Specialist, Department of Plant Sciences, UC Davis; and D.S. Munk is Farm Advisor, UC Cooperative Extension, Fresno County.

\section{References}

Carter LM, Stockton JR, Travernetti JR, Colwick RF. 1965. Precision tillage for cotton production. Trans Am Soc Agr Eng 8:177-9.

Hartwig NL, Ammon HU. 2002. Cover crops and living mulches. Weed Science 50:688-99.

Hernanz JL, Lopez R, Navarrete L, Sanchez-Giron V. 2002. Long-term effects of tillage systems and rotations on soil structural stability and organic carbon stratification in semiarid central Spain. Soil Tillage Res 66:129-41.

Holland JM. 2004. The environmental consequences of adopting conservation tillage in Europe: Reviewing the evidence. Ag Ecosys Environ 103:1-25.

Lu YC, Watkins B, Teasdale JR, Abdul-Baki AA. 2000. Cover crops in sustainable food production. Food Rev Int 16:121-57.

Maas EV. 1986. Salt tolerance of plants. Appl Ag Res 1:12-26.

Mrabet R, Saber N, El-Brahli A, et al. 2001. Total particulate organic matter and structural stability of a Calcixeroll soil under different wheat rotations and tillage systems in a semiarid area of Morocco. Soil Tillage Res 57:225-35.

Potter KN, Torbert HA, Jones OR, et al. 1998 Distribution and amount of soil organic $C$ in longterm management systems in Texas. Soil Tillage Res 47:309-21.

Poudel DD, Horwath WR, Mitchell JP, Temple SR 2001. Impacts of cropping systems on soil nitrogen storage and loss. Ag Systems 68:253-68.

Reeves DW. 1997. The role of soil organic matter in maintaining soil quality in continuous cropping systems. Soil Tillage Res 43:131-67.

Robbins SG, Voss RD. 1991. Phosphorus and potassium stratification in conservation tillage systems.

J Soil Water Conserv 46:298-300.

Tukey JW. 1953. The problem of multiple comparison. Mimeographs. Princeton University, Princeton, NJ.

Uri ND, Atwood JD, Sanabria J. 1998. The environmental benefits and costs of conservation tillage. Sci Total Environ 216:13-32.

Zibilske LM, Bradford JM, Smart JR. 2002. Conservation tillage induced changes in organic carbon, tota nitrogen and available phosphorus in a semi-arid alkaline subtropical soil. Soil Tillage Res 66:153-63. 